\title{
Corrigendum
}

\section{Corrigendum to "Two Mutations in Surfactant Protein C Gene Associated with Neonatal Respiratory Distress"}

\author{
Anna Tarocco, ${ }^{1}$ Elisa Ballardini, ${ }^{2}$ Maria Raffaella Contiero, ${ }^{2}$ \\ Giampaolo Garani, ${ }^{2}$ and Silvia Fanaro ${ }^{2}$ \\ ${ }^{1}$ Pediatric Section, University Hospital S. Anna, Via Aldo Moro 8, 44124 Ferrara, Italy \\ ${ }^{2}$ Neonatal Intensive Care Unit and Neonatology, University Hospital S. Anna, Ferrara, Italy \\ Correspondence should be addressed to Anna Tarocco; anna.tarocco@unife.it
}

Received 21 September 2015; Accepted 8 October 2015

Copyright (c) 2015 Anna Tarocco et al. This is an open access article distributed under the Creative Commons Attribution License, which permits unrestricted use, distribution, and reproduction in any medium, provided the original work is properly cited.

In the paper entitled "Two Mutations in Surfactant Protein C Gene Associated with Neonatal Respiratory Distress" [1], we wrote the following in Section 2 "Tracheal aspirates and blood for molecular typing for surfactant protein were analyzed: DNA sequencing showed two mutations in the SFTPC gene (C43-7G $>A$ and $12 \mathrm{~T}>\mathrm{A})$. Parents refused to be examined." It has to be corrected as follows.

"Tracheal aspirates and blood for molecular typing for surfactant protein were analyzed: DNA sequencing showed two mutations in the SFTPC gene (C43-7G $>A$ and $12 \mathrm{~T}>\mathrm{A})$. The analysis was performed by Clinical and Molecular Biology and Cytogenetics Laboratory, S. Raffaele Hospital (Milan, Italy), directed by Professor Maurizio Ferrari."

\section{References}

[1] A. Tarocco, E. Ballardini, M. R. Contiero, G. Garani, and S. Fanaro, "Two mutations in surfactant protein $\mathrm{C}$ gene associated with neonatal respiratory distress," Case Reports in Pediatrics, vol. 2015, Article ID 591783, 3 pages, 2015. 


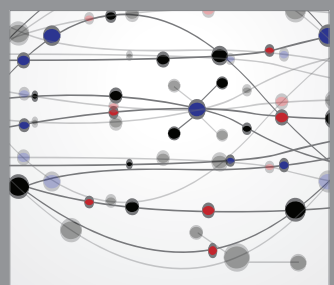

The Scientific World Journal
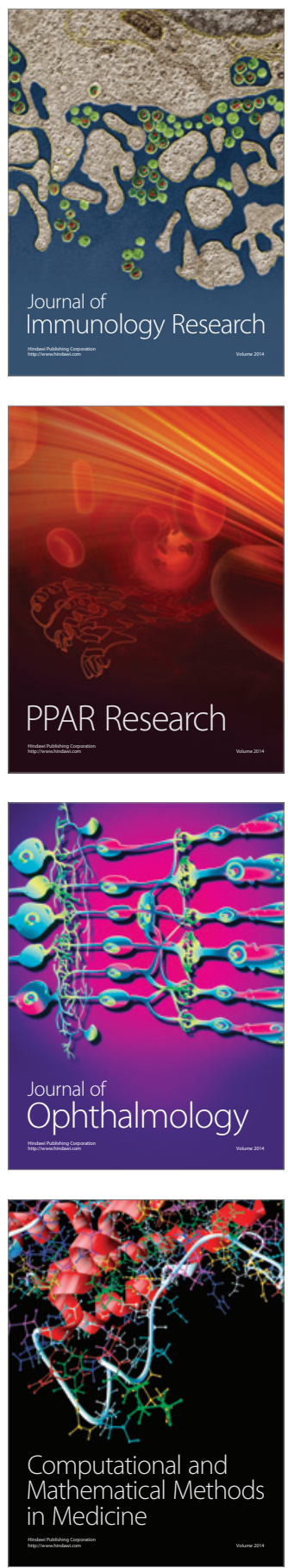

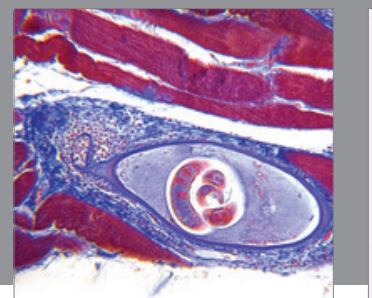

Gastroenterology

Research and Practice
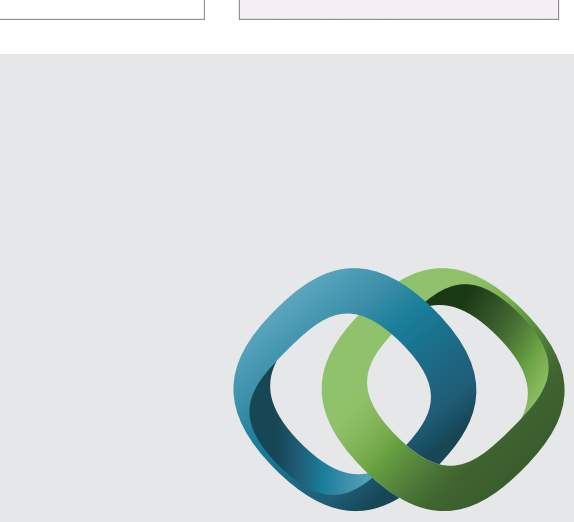

\section{Hindawi}

Submit your manuscripts at

http://www.hindawi.com
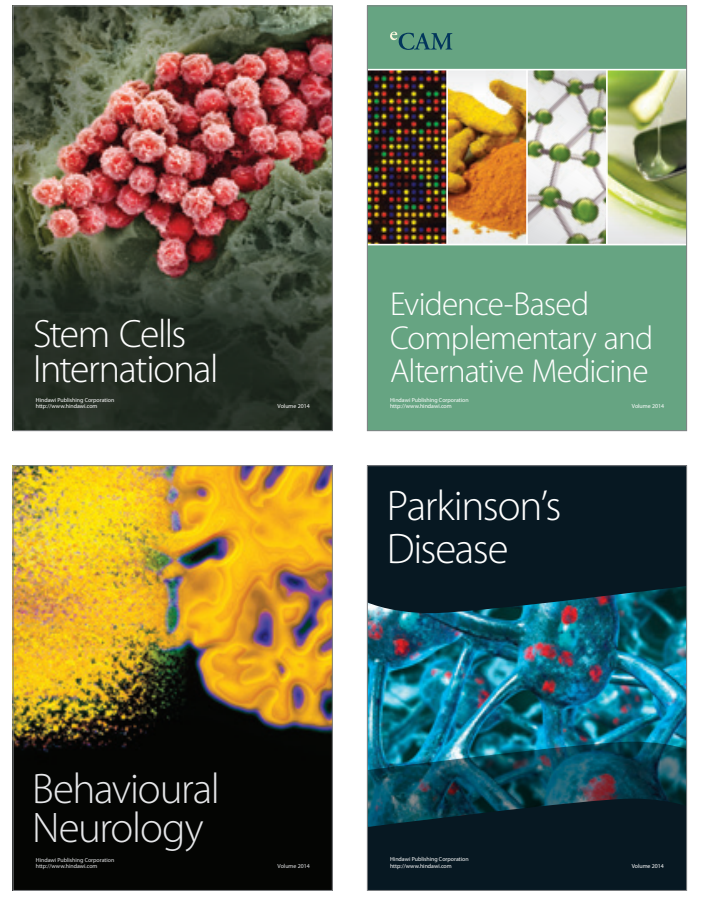
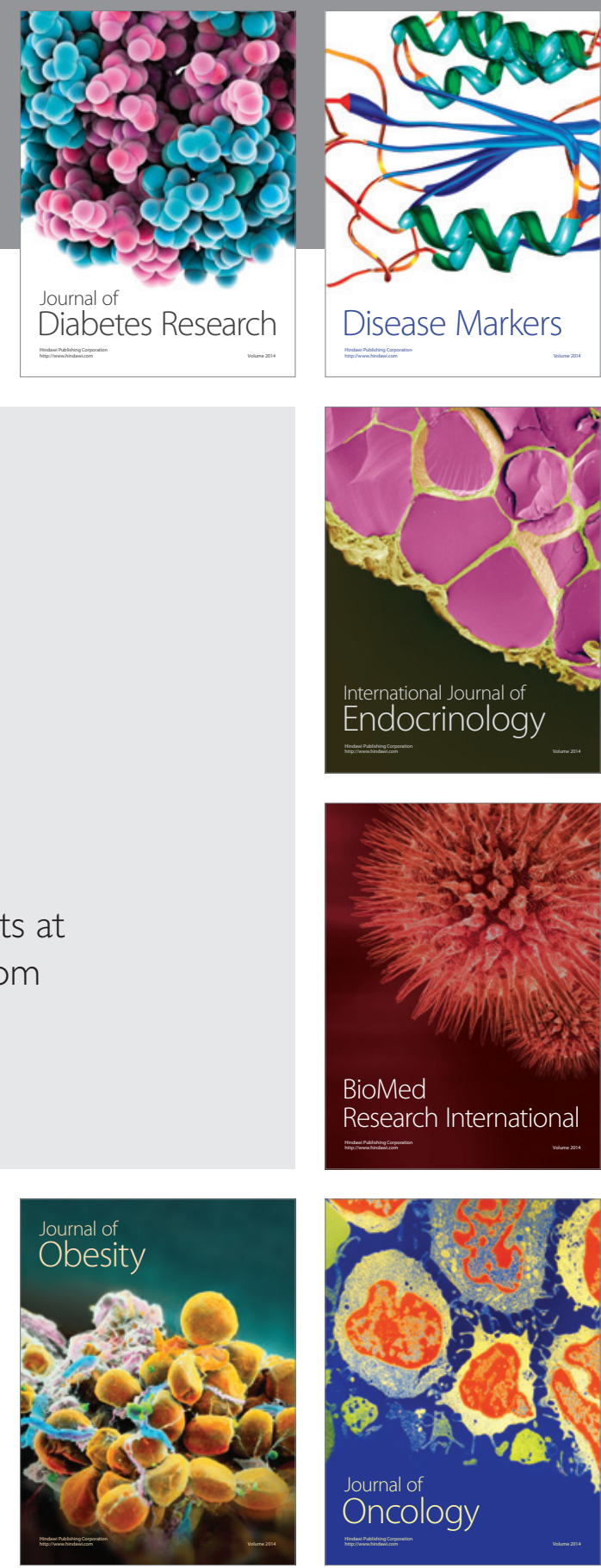

Disease Markers
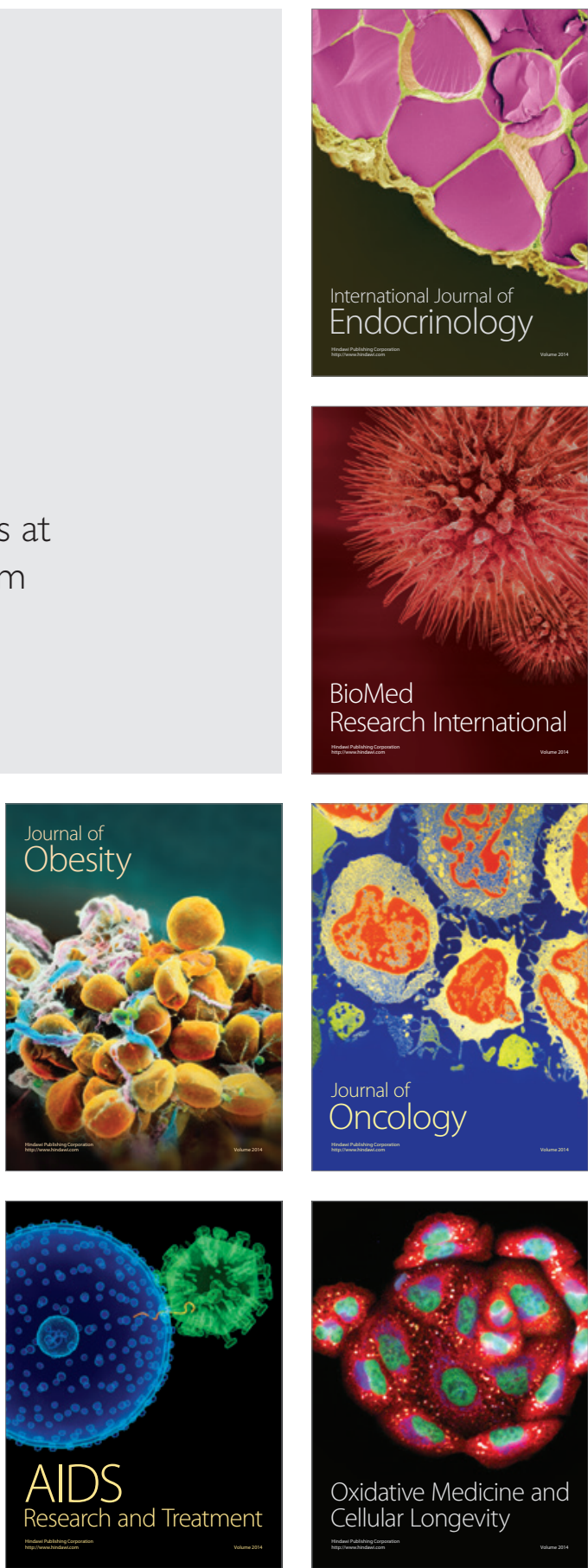